\title{
Evaluation of binders in the production of briquettes from empty fruit bunches of Elais Guinensis
}

\author{
Kenechukwu Ugwu, Kevin Agbo \\ National Centre for Energy Research and Development, University of Nigeria, Nsukka, Nigeria \\ Email address: \\ kenecis@yahoo.co.uk(K.Ugwu), emekagbo185@yahoo.com(K. Agbo).
}

\section{To cite this article:}

Kenechukwu Ugwu, Kevin Agbo. Evaluation of Binders in the Production of Briquettes from Empty Fruit Bunches of Elais Guinensis. International Journal of Renewable and Sustainable Energy. Vol. 2, No. 4, 2013, pp. 176-179. doi: 10.11648/j.ijrse.20130204.17

\begin{abstract}
Briquettes were produced from empty fruit bunches of oil palm plant using starch and asphalt separately as binders. The briquettes were compared based on their physical and chemical properties. The briquettes made with starch as binder had higher calorific value, higher burning rate and higher heat output. It also produced less smoke and ignited within a shorter time than the briquettes made with asphalt as binder. From the results, it will be easier to choose the binders for briquette making between asphalt and starch, though other parameters may be considered.
\end{abstract}

Keywords: Asphalt, Binders, Biomass, Briquettes, Starch

\section{Introduction}

The power supply problem in Nigeria has been severally associated with the country's slow development. The combined power output from the energy sources to the national grid is less than $3,000 \mathrm{MW}$ [1]. This quantity is considered grossly insufficient in view of the population of the country and the growth plan. Petroleum resources provide the fuel for the generation of the highest output of power in Nigeria [2]. Other sources of power generation can complement the supply from the fossil fuel.

Agriculture, as the main occupation of most Nigerians, involves a lot of activities. These activities generate so many wastes which are disposed indiscriminately. It has been found that these wastes can be reintegrated to contribute in solving the energy problem in the country. The harnessing of biomass to make significant contribution to the energy mix has been reported in several research findings [3]. The enormous forest resources and land mass in Nigeria with flourishing vegetation imply that the regeneration of the resources through appropriate means can be a simple way of contributing to solving a seemingly intractable power supply problem. It is common in most Nigerian rural communities to fell trees. The problem of felling trees for the purpose of using it as fuel source impacts adversely on the environment. One way of limiting the deforestation and protecting the environment is by briquetting of the flammable materials. Briquettes are flammable materials formed from the compression or densification of matter into solid form to be used as fuel [4] Briquetting is a process of binding together pulverized carbonaceous matter, often with aid of binder [5]. The common forms of briquettes are the coal briquettes and the biomass briquettes. Biomass briquettes originate from mostly agricultural residues. This includes the charcoal briquettes. By converting the agricultural residues to briquettes, a gamut of advantages is derivable. These include:

- $\quad$ Briquettes provide an easier way of getting energy supply for cooking and ironing of clothes as the briquettes can be transported easily than the agricultural residues

- Briquettes provide cleaner emission than wood and other dried plants usually used for obtaining rural energy supply

- The raw material for making briquettes are sourced from materials that would have been chunked, and as such it converts waste to energy

- Briquettes can be used in stoves and boilers

- Briquetting increases strength, density, heat emitted per volume of the biomass [5]

The conversion of biomass into briquettes by thermal process is a way to enhance its utilization as a source of alternative energy. Briquettes may be produced with or without binders. The particles must bind properly during compression; otherwise, the briquettes might crumble easily. Pressure, heat, moisture, and size reduction are therefore necessary in the process of making high quality briquettes 
[5].

The binders can be organic or inorganic agents. Some of the identified binders of organic nature are heavy crude oil, starch and molasses. The inorganic binders include clay, sodium silicate and cement. The binder types, amount of binder agent and water addition, have significant effects on the thermal behavior and combustion of the briquettes [6]. The combustion characteristics of the briquettes may be determined based on different parameters such as the reaction kinetics and the water boiling tests.

In this study, the influence of the different binders was examined from the combustion characteristics of briquettes produced from empty fruit bunch of oil plant (Elais Guinensis) in which the binders were used.

The palm oil plants are found in most parts, especially, southern states of Nigeria. The different parts of the oil palm are utilized for different purposes. While the leaves provide brooms for tidying the environment, the kernel is a major source of red palm oil used for cooking. The seed is the source of palm kernel oil (PKO) used extensively in the pharmaceutical and cosmetic industries. In the palm oil processing operations, the solid wastes are:

- Empty fruit bunches,

- Palm fibre, and

- Palm kernel shell.

Nigeria is the third highest producer of palm oil in the world. It produces 0.8 million tonnes per year $\left(8.0 \times 10^{5}\right.$ $\mathrm{tyr}^{-1}$ ), of palm oil from $3.6 \times 10^{6} \mathrm{tyr}^{-1}$ of fresh fruit bunches with corresponding 0.82 million tonnes of Empty fruit bunches (EFB). EFB constitute about $22 \%$ of solid waste from palm oil processing.

The EFB can be converted into briquettes, a solid fuel. In this form, the EFB can be used in domestic cooking as well as in ironing of clothes, amongst other uses. It can even be used to raise steam in boilers as already being utilized in some Far East countries.

In rural community levels, EFB are lit and the flame used in cooking. However it burns with a lot of smoke due to its organic content. The negative effects of such smoke to health cannot be over emphasized. Even with the use of EFBs in rural areas, they are still common sight at rural refuse dumps due to the large quantity of the EFBs available. Carbonizing and briquetting of EFBs would make for efficient and sustainable use of EFBs. This work is to harness EFBs to make a contribution to the energy mix. The EFBs were converted into briquettes by adopting very simple processes, utilizing readily available and affordable materials. In addition, two types of binders were compared. The briquettes produced from EFBs with asphalt as binder, and with starch as binder, were tested for their combustion and physical characteristics.

\section{Materials and Method}

The Empty Fruit Bunches waste was collected from oil mill refuse dumps at Nsukka and dried under the sun. The fibres of the Empty fruit bunches of the oil plant were carbonised using the simple drum method [7]. In this process, a metal container was perforated underneath. The EFB filled about one-fifth of the container size. The container was placed on a stand and about $3 \mathrm{~mL}$ of kerosene was sprinkled on the EFB to facilitate ignition. This was followed by application of heat underneath the container. The EFBs ignited after about four minutes and were allowed to burn until the flame became bluish and the EFB turned black. The container was brought down from the stand and remained for 8 hours while being tightly covered to prevent the entry of air. After this period, the charcoal had formed with no ash.

The charcoal produced from the carbonization was ground with a blender. The ground particles were filtered with a mesh. The gross sample was then mixed thoroughly and divided into two parts. One part was mixed with starch made from cassava flour while the other part was mixed with asphalt which was collected from a roadwork site. The mixing proportion was about $18 \%$ binder to the sample.

The samples which had been blended with the binders were manually pressed into moulds and solar- dried for four days. No briquetting machine was used as this work is intended to be helpful to the rural people who may not afford or have access to briquetting machines. After the drying process, different tests were conducted on the briquettes. The physical, combustion properties and water boiling tests (WBT) were carried out on the briquettes.

The following tests were conducted on the briquettes at National Centre for Energy Research and Development Laboratory at the University of Nigeria, Nsukka:

\subsection{Calorific Value}

The Calorific values of the briquettes were determined using an oxygen bomb calorimeter model XRY-1A.

\subsection{Moisture Content}

The moisture content was determined by the use of MB35 Halogen Ohaus moisture analyser.

\subsection{Ignition Test}

About $2 \mathrm{~mL}$ kerosene was used for the ignition.

\subsection{Combustion Analysis}

The combustion tests were carried out by boiling water (water boiling test), using the normal materials in a typical rural household [8]. This was to simulate cooking condition. An open air stove was used. A known quantity of water (1.5L) was measured into a cooking pot whose weight had been noted. Some lumps of the briquettes were placed on the cooking stove after they were weighed. The briquettes were sprinkled with about $2 \mathrm{~mL}$ of kerosene for ignition. After the briquettes had ignited and the kerosene had burnt out, the pot of water was placed on the stove. This was after the initial temperature of the water had been noted. The temperature of the water was noted at intervals of five minutes until the water boiled at $363 \mathrm{~K}$. The weight of the 
evaporated water was calculated from the difference between the final weight of water after cooling and the initial weight of water in the pot. The weight of the briquette burnt was calculated from the difference in the initial weight of briquettes put on the stove and the final weight after the water had boiled.

\section{Results and Discussion}

The comparison of the parameters obtained from the briquettes made with starch as the binder and with asphalt as the binder is provided in table 1 below. The results were from average of triplicate analysis. The results of the water boiling tests were used to calculate the percentage heat utilized, power output, burning rate and the specific fuel consumption.

Table 1. Results of tests on the Briquettes

\begin{tabular}{|c|c|c|c|}
\hline S/No & Parameter & $\begin{array}{l}\text { Starch Binder } \\
\text { EFB Briquette }\end{array}$ & $\begin{array}{l}\text { Asphalt } \\
\text { Binder EFB } \\
\text { Briquette }\end{array}$ \\
\hline 1 & $\begin{array}{l}\text { Physical } \\
\text { appearance }\end{array}$ & $\begin{array}{l}\text { Black colour, } \\
\text { smooth to touch }\end{array}$ & $\begin{array}{l}\text { Darker } \\
\text { colour, } \\
\text { smoother to } \\
\text { touch }\end{array}$ \\
\hline 2 & $\begin{array}{l}\text { Calorific value } \\
(\mathrm{kJ} / \mathrm{kg})\end{array}$ & $20,438.40$ & $18,406.36$ \\
\hline 3 & Moisture content & $6.01 \%$ & $10 \%$ \\
\hline 4 & Ignition time & $\begin{array}{l}6 \text { minutes with } \\
\text { ignition aid }\end{array}$ & $\begin{array}{l}13 \text { minutes with } \\
\text { ignition aid }\end{array}$ \\
\hline 5 & $\begin{array}{l}\text { Percentage Heat } \\
\text { Utilized }\end{array}$ & $6.64 \%$ & $3 \%$ \\
\hline 6 & Power output & $1.56 \mathrm{~kW}$ & $1.46 \mathrm{~kW}$ \\
\hline 7 & Burning rate & $4.35 \mathrm{~g} / \mathrm{min}$ & $3.7 \mathrm{~g} / \mathrm{min}$ \\
\hline 7 & $\begin{array}{l}\text { Specific fuel } \\
\text { consumption }\end{array}$ & $0.7 \mathrm{~kg}$ & $0.9 \mathrm{~kg}$ \\
\hline 8 & Smoke & $\begin{array}{l}\text { Burnt with faint } \\
\text { smoke which } \\
\text { vanished with } \\
\text { time. }\end{array}$ & $\begin{array}{l}\text { Burnt with } \\
\text { higher level of } \\
\text { smoke }\end{array}$ \\
\hline 9 & Odour & $\begin{array}{l}\text { Burnt with no } \\
\text { odour }\end{array}$ & $\begin{array}{l}\text { Burnt with no } \\
\text { odour }\end{array}$ \\
\hline
\end{tabular}

From the results given above, the briquettes made with starch as binder had a higher calorific value at $20,438.40 \mathrm{~kJ} / \mathrm{kg}$ than the briquette made from asphalt which has the calorific value of $18,406.36 \mathrm{~kJ} / \mathrm{kg}$.

The ignition time with the asphalt EFB was higher at 13 minutes compared to 6 minutes with starch binder. The power output and the burning rate showed that the EFB briquette made with starch had better output. The asphalt briquette produced more smoke and this is undesirable as smoke has adverse health and environmental implication [9,10] (Bruce, et al., 2000; Mahanama, 2008).
Table 2. Comparison of calorific values of oil palm parts

\begin{tabular}{ll}
\hline Fuel & Calorific value (kJ/kg) \\
\hline Palm kernel Shell & $18,611.7$ \\
Palm kernel oil [11] & 38,025 \\
Palm kernel cake [11] & 18,884 \\
Palm kernel charcoal & $9,118.75$ \\
Palm kernel charcoal briquette & $23,603.28$ \\
Empty fruit bunches [12] & 18,838 \\
Saw dust [13] & 18,936 \\
\hline
\end{tabular}

\section{Conclusion}

Briquettes were produced from EFT using starch as binder in one experiment and asphalt as binder in the second experiment. The EFB briquettes made with starch as binder had better desirable performances. The briquettes produced can be used in domestic cooking, in ironing of clothes, and in industrial heating such as in bakery and in raising steam in boilers. These will obviously diversify the power sources and also convert the EFBs to useful energy products.

\section{References}

[1] D. Okafor, "Coal Resources of Nigeria", paper presented at the International Workshop on Promotion of Coal for Power Generation at Enugu, Nigeria, in April, 2009, unpublished.

[2] U. B. Bindir, "Technology Acquisition and Promotion in the Power Sector", paper presented at the International Workshop on Promotion of Coal for Power Generation at Enugu, Nigeria in April, 2009, unpublished.

[3] T.C. Ogbuanya, Energy and Technology of Home Appliances, Enugu: Cheston Limited, 2005, p102.

[4] "Briquettes", http://en.wikipedia.org (wiki)Briquette, retrieved on July 2, 2013

[5] J.F. Martin, J.M. Pineda, and A. Ocreto, "Design and development of charcoal briquetting machine," USM R \& D, vol. 16(2), pp85-90, 2008.

[6] N. Altun, C. Hicyilmaz, and A. Bagci, "Combustion Characteristics of Coal Briquettes (Thermal features)", Energy \& Fuels, Vol. 17, pp1266-1276, 2003.

[7] E. Walter,"Handbook of Charcoal Making: The Traditional and Industrial Methods", Dordrecht, NL: Reidel, p300, 1985.

[8] O.A. Kuti, "Performance of Composite Sawdust Briquette fuel in a Biomass Stove under simulated condition". AU J.T. vol. 12 (4), pp284-288, 2009.

[9] N. Bruce, R. Perez-Padalla and R. Albalak, "Indoor air pollution in developing countries: a major environmental and public health challenge". Bulletin of World Health Organisation vol. 78(9, pp1078-1092, 2000

[10] K.R.R. Mahanama, “Cooking or being cooked”, Economic 
reviews, vol.34(384, pp18-23, 2008

[11] A.N. Ma and Y. B. Dato, "Biomass Energy from the Palm oil industry in Malaysia", The Ingenieur, vol. 27, pp18 - 25, 2005.

[12] S. Vijaya, M.C. Chow, and A.N. Ma, "Energy Database of the Oil Palm". MPOB Palm oil Engineering Bulletin, vol. 70, pp15-22, 2004.

[13] A. Nasrin, A.N. Ma, Y.M. Choo, S. Mohama, M.H. Rohaya,and Z.Zainal, "Oil Palm Biomass as Potential Substitution Raw materials for Commercial Biomass Briquettes Production", American Journal of Applied Sciences, Vol. 5 (3), pp179-183, 2008. 